\title{
Made in Medieval: a ‘exportação' do Medievalismo e a compreensão da História Africana
}

\begin{abstract}
Made in Medieval: the 'export' of Medievalism and the comprehension of African History
\end{abstract}

\section{Otávio Luiz Vieira Pinto}


Resumo: Este artigo objetiva construir uma discussão acerca da viabilidade de se pensar a África ao Sul do Saara enquanto um espaço possuidor de uma “Idade Média”. Para tal, apresento uma breve discussão da genealogia do termo Medieval, Estudos Medievais e Medievalismo. Esta digressão é importante para que se perceba a relação íntima entre a historiografia sobre a Idade Média e a Europa. A partir disso, discuto as propostas “deseurocentralizadoras" que vem com a abordagem pós-colonial dos Estudos Medievais e, a partir disso, discuto as implicações de se pensar um Medievo fora da Europa, em especial na África ao Sul do Saara. A partir destas reflexões, concluo que a tentativa de enquadrar espaços africanos na cronologia de uma Idade Média atua como uma forma de exportação de um Medievalismo Acadêmico: a África ao Sul do Saara se torna, mais do que um objeto de análise, um campo de criação de imagens idealizadas, romantizadas e instrumentalizadas com implicações epistemológicas e políticas para a compreensão histórica do continente. Portanto, o termo “África Medieval” não é neutro e precisa ser constantemente repensado e problematizado.

Palavras-chave: África; Medievalismo; Historiografia; Mansa musa; Império do Mali.

Abstract: This paper aims to discuss the viability of thinking Africa South of the Sahara as a space with its own "Middle Ages". To do so, I briefly discuss the genealogy of the term Medieval, Medieval Studies and Medievalism. This digression is important in order to observe the intimate relation between historiography on the Middle Ages and Europe. Then, I discuss the "non-eurocentric" proposals that come with a Postcolonial approach to Medieval Studies and, after that, I discuss the implications of conceiving a Middle Ages outside of Europe, especially in Africa South of the Sahara. I conclude arguing that attempting to frame African spaces in a chronology of Middle Ages acts as a type of export of a Academic Medievalism: Africa South of the Sahara becomes, more than na object of 
study, a field where idealized, romantic and instrumentalized images are created, setting forth epistemological and political implication for our historical understanding of the continent. Therefore, the idea of a "Medieval Africa" is not neutral and has to be constantly questioned. Keywords: Africa; Medievalism; Historiography; Mansa musa; Mali empire. 


\section{Introdução: África Livre, África Medieval ${ }^{2}$}

Em 1957, Astley John Hilary Goodwin, então professor associado de arqueologia sul-africana na Universidade da Cidade do Cabo, publicou um artigo intitulado The Medieval Empire of Ghana. Sua narrativa se baseava em um ponto muito simples: a História da África Ocidental era misteriosa para os europeus, e sua pesquisa visava dissipar a névoa do desconhecimento. Para Goodwin, a África Ocidental, isto é, as sociedades negras do Saara e do Sahel, estavam intimamente ligadas aos "líbico-bérberes” norte-africanos, que atuavam como uma força civilizatória. Conclui-se, portanto, que a designação Medieval, aqui atribuída ao "Império do Ghana”, visava facilitar a localização temporal do leitor europeu - explicitamente entendido como o público alvo do artigo -, ao mesmo tempo em que submetia o desenvolvimento histórica da África Negra ao Norte da África, uma região que, segundo Goodwin, era formada pelo "galho africano da raça mediterrânica” (GOODWIN, 1957, p. 108).

A “medievalização” da África, operada por Goodwin com ares de ineditismo, fazia parte de um movimento historiográfico que ganhava popularidade nos anos 1950 e 1960 entre os africanistas. Em 1952, o notório arqueólogo britânico James Kirkman publicou o artigo The Excavations at Kilepwa: an Introduction to the Medieval Archaeology of the Kenya Coast. Em seu texto, Kirkman utiliza o termo Medieval somente uma vez - no título. Vê-se, aqui, como no caso de Goodwin, a mesma tentativa de, meramente, localizar o leitor europeu em um determinado recorte cronológico (KIRKMAN, 1952). 10 anos depois, Greville Freeman-Grenville lança seu The Medieval History of the Tanganyika Coast. Como fizeram Kirkman e Goodwin anos antes, Freeman-Grenville opta por adotar o designativo temporal Medieval já em seu título (FREEMAN-GRENVILLE, 1962). Tem-se então um recado poderoso: existe uma África Medieval, e ela ainda é desconhecida, cercada de mistérios e desconhecimentos. Subjacente à essa localização temporal - relativamente inovadora para a época -, há também o ímpeto de submeter a História da África Negra à narrativa mais ampla da História do Islã, seja aquele Islã que se espalha pelo Norte da África ou aquele que reverbera na África Oriental a partir da Península Arábica e do Planalto Iraniano.

Esta releitura temático-cronológica da África Negra, a partir das sociedades sahelianas ou das sociedades da costa oriental, surge na iminência das lutas de descolonização africanas da segunda metade do século XX. Kirkman, por exemplo, lança seu artigo sobre a escavação de Kilepwa no mesmo ano em que 
eclode a Revolta dos Mau-Mau no Quênia (MALOBA, 1998, p. 64-80). Goodwin, por sua vez, escreve sobre o "Império Medieval do Ghana” ao mesmo tempo em que a Costa do Ouro Britânica consegue independência e se torna, justamente, a República do Gana (GOCKING, 2005, p. 115-147). De forma semelhante, Freeman-Grenville discute a "História Medieval de Tanganyika” um ano após o Ato de Independência de Tanganyika de 1961, e 2 anos antes da efetiva formação de um novo estado, a Tanzânia, resultante da união entre Tanganyika e Zanzibar em 1964 ( $c f$. BJERK, 2015). Assim, pode-se argumentar que as transformações políticas que se espalhavam rapidamente pelo continente influenciaram as Ciências Humanas a buscar novas narrativas históricas que apresentassem e explicassem o passado das jovens nações que emergiam dos escombros do imperialismo.

Contudo, como vimos acima, estas explicações eram voltadas para o público europeu. Por isso, localizar passados africanos no molde do Medieval era especialmente importante: isso gestaria histórias temporalmente familiares, cuja referência temática era o próprio passado europeu. Esta implicação epistemológica, fundamental para que possamos apreciar o peso real da terminologia cronológica do Medieval, mantém essa valoração explicativa mesmo quando a historiografia que lida com a Idade Média passa por viradas críticas e decoloniais - algo que será discutido mais adiante. Assim, referenciar a História da África partindo de balizas pré-concebidas (como é o caso do Medieval) permitiria abordagens integradoras, amplas e inclusivas: o continente africano também compartilharia a metanarrativa histórica do Velho Mundo. Contudo, é possível pensar que, mesmo nos momentos mais conscientes e autocríticos da historiografia, a “medievalização” da África abandone este Olhar Europeu que transforma a narrativa do passado à sua imagem e semelhança? Qualquer tentativa de resposta a essa pergunta requer que entendamos, em primeiro lugar, a razão pelo qual o Medieval evoca uma perspectiva histórica eurocentralizante. E essa razão está no DNA da terminologia.

\section{Uma Genealogia Medieval}

A Idade Média nasceu na Itália. Não foi um conjunto de eventos ou uma condição sócio-cultural específica que deu origem ao Medieval italiano. Foi, na verdade, a pena e o nanquim de uma série de escritores do século XIV e além. Desde Francesco Petrarca, pairava junto aos humanistas a ideia de um interregno temporal, um período entre a grandeza da Antiguidade Greco- 
Romano e a nascente dinâmica de artes e ciência que se enraizava nas repúblicas italianas e marcava o tempo destes escritores (MOMMSEN, 1942, p. 226 - 242). O tempo, fatiado em etapas, certamente não era estranho para os pensadores da Europa: como notou George Burr em 1913, Otto de Freising, no distante século XII, já compreendia uma história tripartite: “até Constantino, o Mundo; desde Constantino, a Igreja Militante; à frente, a Igreja Triunfante” (BURR, 1913, p. 715). Dividir a História seguia, até então, uma pulsão religiosa. Narrativas do Apocalipse ou profecias como a dos Quatro Impérios de Daniel davam, aos judeus e aos cristãos, um senso escatológico na narração dos tempos, propenso à categorização (VENTER, 2000, p. 667-669). A vinda de Cristo certamente marcava uma ruptura intensa no tempo - tempo que, para Agostinho, era da própria essência divina. Se Deus é o início do passado, Cristo era a marca do presente e, sua Segunda Vinda, o Julgamento, o indício do futuro. Entre o início, o meio e o fim, as vicissitudes da humanidade se desenrolam. Assim, a História em Pedaços chega aos Humanistas, que logo a sistematizam. Em 1469, Giovanni Andrea Bussi, bibliotecário papal, organiza uma edição do Asno de Ouro, de Apuleio. Em seu prefácio, Bussi reitera seus conhecimentos de História, não apenas da Antiguidade, sed mediae tempestatis [...] usque ad nostra tempora (MIGLIO, 1978, p. 17). "Mas [também] da Idade Média [...] até o nosso tempo". Em 1518, o suíço Joachim von Watt falava de uma Media Aetas e, quase ao mesmo tempo, o alsácio Beatus Bild (ou Beatus Rhenanus) eternizava o termo Media Antiquitatis (SCHAEFFER, 1976, p. 21 - 23). Com raízes entranhadas em Petrarca e Bussi, o século XVI cria então um novo tempo, o “Tempo do Meio", não mais guiados por uma noção religiosa de cronologia, mas por uma noção estética e cultural, que separe os pensadores que surgem entre os séculos V e XIII deles próprios. Já entre os séculos XVII e XVIII, o Medieval parece ganhar um corpo verdadeiramente histórico-cronológico: em 1702, o turíngio Christoph Cellarius publica, em três volumes, um compêndio de suas pesquisas históricas, chamado Historia universalis breviter ac perspicue exposita, in antiquam, et medii aevi ac novam divisa, cum notis perpetuis, ou "História Universal exposta clara e brevemente, e dividida em Antiga, Idade Média e Nova, com notas contínuas”. Baseando-se em italianos como Leonardo Bruni e Flavio Biondo, Cellarius populariza definitivamente a divisão tripartite da História: Antiga, Medieval e Contemporânea (REUTER, 1998, p. 27-28).

A Idade Média, então, nunca existiu. Foi criada. Foi concebida e escrita como um período de alteridade. Primeiro, alteridade estética e cultural. Com o tempo, o Medieval foi ganhando contornos mais claros. Os movimentos 
românticos do século XIX, em especial, buscaram definir o período mais além. Ganhou contornos políticos, sociais, religiosos, econômicos, marciais, etc. Em outras palavras: entre os séculos XVI e XIX, a Idade Média se torna um período histórico bona fide: delimitado, definido, mais ou menos hegemônico. Com o surgimento do Medieval, surge também o medievalista, o especialista na lida com a documentação e o pensamento do período que vai, grosseiramente, do final do Império Romano à Queda de Constantinopla. Enquanto o Medieval nasce na Itália, o medievalista nasce na Inglaterra: o termo ganha tração a partir da fundamental obra de Henry Hallam, View of the State of Europe during the Middle Ages, ou "Análise do Estado da Europa durante a Idade Média" (cf. HALLAM, 1866). Ao lado da Itália e da Inglaterra, França e Alemanha também se tornam bastiões fundamentais dos Estudos Medievais. Na França, a revista burguesa $L a$ Revue des Deux Mondes, na década de 1870, populariza enormemente a ideia de Idade Média fora dos círculos de pesquisa acadêmicos (EMERY, 2000, p. 99), enquanto nomes como Gaston Paris, Francisque Michel e Jules Michelet o fazem junto aos círculos letrados. Na Alemanha, o Medieval abrolha como um campo de estudo rigoroso, preocupado com os arquivos e as fontes: em 1826, surge o primeiro volume da Monumenta Germaniae Historica, sob curadoria de Georg Heinrich Pertz. A Monumenta Germaniae Historica, ainda em atividade, é uma titânica coleção de documentos, temporalmente localizados entre o Império Romano e o "final da Idade Média”. Por ela, passam grandes antiquistas e medievalistas germânicos, como Georg Waitz, Johann Friedrich Böhmer, Theodor Mommsen, Bruno Krush e dezenas de outros (FUHRMANN, 1996, p. 65-76).

Nos entremeios da institucionalização da História, enquanto disciplina acadêmica, e do romanticismo que desperta no seio da Europa novecentista, os Estudos Medievais deixam claro uma faceta que rapidamente se incorpora ao seu DNA: o nacionalismo. O Medieval se torna uma peça chave para a construção de nações, para o ordenamento dos variados passados pós-romanos, para a exploração e exaltação de costumes, línguas e práticos romance-germânicas. Diante dessa instrumentalização política do passado, o Medieval se manifesta também fora da Academia. As artes plásticas, a música, a literatura e a arquitetura são alguns dos campos que, no século XIX, passam a adotar uma estética medieval imaginada ( $c f$. GEARY; KLANICZAY, 2013). O movimento Nazareno, na Alemanha, e a Irmandade Pré-Rafaelita, na Inglaterra, são algumas dessas ondas artísticas (ROBERTS, 1992, p. 15-28). Na música, as famosas óperas de Carl Maria von Weber, Franz Schubert, Heinrich Marschner e Richard Wagner 
passeiam por essa pretensa medievalidade ( $c f$. RICHARDSON, 2016). Na literatura, até mesmo acadêmicos se aventuram na palatização do Medieval ao gosto popular: François-René de Chateaubriand e seu Les Martyrs, Felix Dahn e seu Kampf um Rom ou o clássico Ivanhoe de Walter Scott são alguns exemplos (WOOD, 2017, p. 37-53).

Historiadores profissionais, preocupados com a autoridade científica de suas cátedras, buscam certo distanciamento deste Medieval que se populariza e ganha corpus artístico (STOKES, 2020, p. 17). Assim, a partir dos anos 1840 ou 1850, um novo termo começa a circular nos espaços ingleses: Medievalism. O termo é comumente atribuído ao crítico de arte vitoriano John Ruskin, que o pronunciou em uma palestra em 1853; contudo, artistas como Dante Gabriel Rossetti já falavam sobre Medievalismo em 1851, significando uma apropriação estética de elementos percebidos como medievais (MATTHEWS, 2011, p. 707). Enquanto Ruskin associava os significados de Medieval e Medievalismo, Rossetti e outros, como o pintor John Everett Millais empregavam Medievalismo em um sentido que parecia mais comum, justamente no sentido de "reapropriação do Medieval" (MATTHEWS, 2011, p. 707-708). De uma forma ou de outra, temos então a existência de um termo que permite a diferenciação entre o Medieval que é estudado pela Academia (Estudos Medievais) e o Medieval que é apreendido por movimentos populares de arte e entretenimento (Medievalismo). Em outras palavras, a partir de metade do século XIX, temos um termo específico - Medievalismo - para designar instâncias em que o presente se apropria de um passado considerado medieval; esta apropriação não pretende ser, necessariamente, acurada ou fiel à historiografia, mas trabalha em cima de elementos estéticos, topoi imaginados e estereótipos facilmente reconhecíveis. A intencionalidade por trás do Medievalismo também não é, necessariamente, pedagógica ou investigativa, mas pode buscar entretenimento ou aplicação política. Com o tempo, o Medievalismo deixa de ser entendido apenas como um fenômeno não-acadêmico de apropriação do passado para se tornar também um campo de estudos desta apropriação: em especial a partir dos anos 1970, os seminais esforços de Leslie Workman fazem com que o Medievalismo deixe de ser entendido apenas como uma forma de Usos do Passado, mas se torne também uma área de estudos próprio do medievalista (VERDUIN, 2009, p. 1-27): também chamado de Neomedievalismo, este formalizado campo de investigação das apropriações do pretéritas surge porque, como aponta Amy Kaufman, os avanços de perspectivas Pós-Modernas, na episteme das Ciências Humanas, operaram uma separação entre o Medievalismo “clássico" e seu próprio objeto, 
isto é, o que é efetivamente entendido como Medieval (KAUFMAN, 2010, p. 2-3). Assim, a ascensão do Medievalismo como uma área de estudos é fruto dos impactos teóricos e filosóficos que se desenham a partir dos anos $1960 .{ }^{3} \mathrm{O}$ desenvolvimento desta discussões e os trânsitos interdisciplinares fazem com que, na passagem do século XX para o século XXI, o Medievalismo enquanto campo dos Estudos Medievais, ganhe tração e maturação, como demonstram importantes textos de cunho teórico-metodológico ( $c f$. AURELL, 2006; ALTSCHUL, 2008; UTZ, 2011).

A exposição da genealogia dos Estudos Medievais e do Medievalismo, até aqui, nos permite postular alguns pilares interpretativos: entre os séculos XIV e XIX, o desenvolvimento da ideia de Idade Média passa por caminhos polissêmicos: por vezes, encarna alteridade e negatividade, mas também encarna concepções estéticas, desejos românticos nacionais e instrumentalizações que implicam em certa positividade. Com o estabelecimento de um campo disciplinar do Medieval a partir das estratégias metódicas da historiografia novecentista, os juízos de valor são relegados às interpretações populares, ou seja, ao Medievalismo, enquanto que os Estudos Medievais procuram a neutralidade documental: Wie es eigentlich gewesen, "como realmente foi", nas palavras do alemão Leopold von Ranke (WOOD, 2013, p. 177). Contudo, na polissemia do que se compreende como Medieval, da visão de "Idade das Trevas" ou das interpolações românticas até à pretensão pela neutralidade metódica da análise documental, um elemento se destaca de maneira homogênea: Estudos Medievais e Medievalismos carregam a marca do nacionalismo (cf. GEARY, 2002).

O que isso significa? Com relação aos Estudos Medievais, temos, grosso modo, um campo de estudos marcado por uma cronologia. Ela pode ser flexível e questionável, mas invariavelmente estamos falando de um espaço temporal reconhecível. Este espaço temporal diz respeito ao desenvolvimento histórico de sociedades europeias. Esforços para "globalizar" os Estudos Medievais vem ocorrendo cada vez em maior intensidade, mas a própria origem da ideia de Idade Média depende de balizas europeias, de eventos europeus e de realidades europeias. O Medieval como parte de uma narrativa histórica "mestra" e nacionalizada se torna ainda mais explícito quando olhamos para o Medievalismo (DUSSEL, 2005, p. 25-32). Como fenômeno eminentemente estético, as manifestações do Medievalismo deixam pistas de sua carga europeia: as imagens recorrentes de catedrais, castelos, cavaleiros, armaduras, trovadorismo, heroísmo, feudos, reis e bispos nos remetem para narrativas eurocentradas, visto que estes estereótipos populares são ocidentais, cristãos 
e europeus.

Se os Estudos Medievais, portanto, são restritos à uma cronologia que segue balizas contextuais europeias e busca investigar, em sua esmagadora maioria, expressões de sociedades europeias, é possível pensar em um mundo Medieval que vai além da Europa? Voltamos, assim, à pergunta proposta anteriormente e que voltará a guiar este texto: é possível pensar em uma Idade Média africana? Para além do norte mediterrânico, os espaços Africanos ao Sul do Saara são contemplados pela ideia do Medieval? A resposta mais simples para esta pergunta é bastante direta: não. Não é possível falar de uma “África Medieval”. A resposta mais complexa, por outro lado, está ancorada justamente nas aproximações e nos distanciamentos entre os Estudos Medievais e o Medievalismo. A digressão acima, ainda que excessivamente simplificada e generalizante, nos ajudará a refletir sobre essa questão.

\section{O Medievo sai da Europa}

Em 2009, Simon Gaunt faz a pergunta retórica que abre seu artigo de revisão teórica dos Estudos Medievais: “pode a Idade Média ser pós-colonial?” (GAUNT, 2009, p. 160-176). A pergunta é motivada por questões genealógicas da própria historiografia, como discutido acima. Se os Estudos Medievais nascem como alteridade à Antiguidade e à Modernidade, e se eles se solidificam a partir parâmetros nacionalistas europeus, é preciso “decolonizar” o campo de estudos e ir além, explorar uma historiografia “pós-colonial” no sentido da superação de sua condição de nascimento. Como explicita Jeffrey Cohen em um seminal volume organizado em 2000, a proposta de uma “Idade Média pós-colonial” é a de retirar do Medievo sua natureza transitória entre o Antigo e o Moderno; repensar, a partir de Edward Said, a neutralidade dos argumentos historiográficos dos Estudos Medievais; desestabilizar noções hegemônicas de identidade, como raça e gênero; romper com a dominação do Cristinianismo, no sentido de expandir o uso de fontes e de tradições sócio-religiosas; e, acima de tudo, descentralizar a Europa, ou seja, buscar uma Idade Média que inclua os espaços da Ásia e da África (COHEN, 2000, p. 6-7). Apesar da ominosa advertência de Gabrielle Spiegel acerca da impossibilidade de se aplicar uma estrutura teórica que surge para explicar espaços específicos em momentos específicos (no caso, a Pós-Colonialidade e a Decolonialidade) ao período pré-Moderno, como é o caso da Idade Média (SPIEGEL, 2000, p. 249-250), a proposta pós-colonial dos medievalistas é menos ambiciosa, pois não se trata de uma nova abordagem 
metodológica per se, mas sim de uma nova perspectiva de leitura: ler o Medieval para além dos nacionalismos, do eurocentrismo, do ceticismo moderno, das categorias estanques e da alteridade. Em outras palavras, os Estudos Medievais pós-coloniais são, em grande parte, Estudos Medievais que olham para suas origens e que percebem que há um mundo além da Europa.

Ainda que separados por departamentos universitários, os Estudos Islâmicos, preocupados com os textos e as culturas que surgem no seio de sociedades muçulmanas a partir do século VII, em especial aquelas no Norte da África ou do Oeste Asiático, já possuem um diálogo relativamente bem estabelecido com os Estudos Medievais mais eurocentrados. A omissão mais gritante, portanto, fica por conta da Leste Asiático, do Sul Asiático e do Sudeste Asiático. E, claro, da África ao Sul do Saara (por alguma razão, a Idade Média pós-colonial ainda não decidiu se as sociedades originais de Abya-Yala, isto é, do continente que viria a ser chamado de América, fazem parte do escopo do Medieval).

O brado “des-eurocentralizador" dos Estudos Medievais foi atendido por alguns, no caso da África ao Sul do Saara. Já distantes dos estudiosos coloniais, como Goodwin e Freeman-Grenville, em 1992 Dierk Lange publicou seu artigo Ein vernachlässigtes Forschungsgebiet: die Geschichte des westafrikanischen Mittelalters; Patricia McKissack e Frederick McKissack publicaram o The Royal Kingdoms of Ghana, Mali, and Songhay: Life in Medieval Africa em 1995; Pekka Masonen publicou The Negroland Revisited: Discovery and Invention of the Sudanese Middle Ages; Roland Oliver e Anthony Atmore lançaram seu Medieval Africa 1250-1800 em 2001; em 2003, Paulo de Moraes Farias publica seu seminal Arabic Medieval Inscriptions from the Republic of Mali: Epigraphy, Chronicles and Songhay-Tuareg History; ${ }^{4}$ em 2005, David Conrad escreveu seu Empires of Medieval West Africa: Ghana, Mali, and Songhay; Lin Donn e Don Donn preparam o material didático Ancient and Medieval Africa em 2012; em 2013, François-Xavier Fauvelle lançou seu clássico Le Rhinocéros d'Or: Histories du Moyen Âge Africain; e em 2017 Michael Gomez publicou seu importante African Dominion: A New History of Empire in Early and Medieval West Africa (cf. CONRAD, 2005; DONN; DONN, 2012, FARIAS, 2003; FAUVELLE, 2013; GOMEZ, 2017; LANGE, 1992; MASONEN, 2000; McKISSACK; McKISSACK, 1995; OLIVER; ATMORE, 2001). Obviamente estes não são os únicos trabalhos a abordarem sociedades africanas na baliza cronológica da Idade Média, mas são alguns dos mais expressivos trabalhos a incluírem, em seu escopo de análise, o designativo África Medieval.

Dentre estes trabalhos, um ponto em comum chama a atenção. Com 
exceção de Fauvelle, todos os outros estudos estão iminentemente centrados em um espaço e um período específico: a Bacia do Níger e a "Era dos Reinos Sudaneses". Estamos falando aqui, basicamente, das organizações sóciopolíticas que se desenvolvem na África Ocidental entre os séculos III e XVI EC. Popularmente conhecidas como Império do Ghana, Império do Mali e Império Songhay, estes estados fornecem ao medievalista uma chamativa imagem da “África Medieval”, já que são, à primeira vista, grandes impérios com lideranças fortes e centralizadas, com fronteiras mais ou menos estabelecidas e com contatos comerciais e militares com a África do Norte (como já defendia Goodwin). Ademais, partindo da documentação islâmica, é possível traçar uma história política de guerra e sucessão que leva do Império do Ghana ao Império do Mali, e do Império do Mali ao Império Shongay (e aos menos populares Império Fula, Império Wolof e Império N’Gabu). Assim, outros espaços que poderiam se enquadrar na clássica cronologia da Idade Média ficam de fora os medievalistas parecem se importar muito pouco com as cidades portuárias da Costa Suaíli (ligando-as à história do Oceano Índico), com as sociedades da região do Zambeze, como Mapungubwe ou Zimbabwe (deixando estas sociedades para a arqueologia), ou mesmo com os espaços da África Central, tais quais Nsi Kwilu e Kitara (relegando-as à antropologia). ${ }^{5}$ Certamente, estes vácuos de pesquisa podem ser atribuídos à uma série de dificuldades, como por exemplo os entraves linguísticos, a natureza oral e tradicional dos relatos, a incompreensão do material arqueológico, etc. Contudo, acredito que temos outras forças em jogo na explicação deste cenário. Poderíamos dizer que estas forças operam por conta de uma percepção da África que não é necessariamente abarcada pelos Estudos Medievais, mas sim pelo Medievalismo.

A natureza da interpretação histórica reservada à Ghana, Mali e Shongay obedece à imagens familiares, como dito acima. A forma com que estas sociedades são vistas pela historiografia pode ser facilmente encaixada em um ordenamento interpretativo prévio. Em outras palavras, os "Grandes Reinos Sudaneses" ganham sentido quando colocados dentro de quadro epistemológico do Medieval. Assim, o Império do Ghana, que subsiste, grosso modo, dos séculos III ao XI EC, torna-se uma "analogia africana" aos reinos da Antiguidade Tardia europeia - como o reino franco - ou ao califado árabe-bérbere. Busca-se, então, uma narrativa política que explique o poder do rei (ou Gàjànnàaná), a dimensão de suas fronteiras ou seu controle das rotas comerciais de sal e ouro do Saara. Ainda que importantes, estas imagens familiares são delimitações clássicas de uma historiografia europeia, e pouco explicariam as especificidades 
de comunidades políticas africanas como, por exemplo, o peso da oralidade, a relevância das tradições familiares, a lógica ancestral que define os estratos e as camadas sociais, etc. A própria designação dada a este espaço político, “Império (eventualmente Reino) do Ghana” já revela certo eurocentrismo interpretativo: o termo Ghana vem do título régio soninquê Gàjànyàaná (do Soninquê "Guerreiro", in: MOUSSA, 2013, p. 63). Tradições orais nos revelam que o "império" era entendido, na verdade, como Wàgádù, significando "Terra dos Wago", visto que os Wago eram os grupos das principais dinastias que formavam aquela estrutura política (MONTEIL, 1953, p. 360-365). Em outras palavras, as tradições orais da África Ocidental dão conta de nos mostrar que o eixo central daquele espaço eram as famílias (Wago) e não o "rei/guerreiro" (Gàjànnàaná). A ênfase na individualidade régia - e, por isso, Império do Ghana, e não Wàgádù - é um atributo típico dos Estudos Medievais europeus.

Movimento semelhante ocorre com ainda mais intensidade no caso do Império do Mali. Compreendido entre os séculos XIII e XVI, o "Mali imperial" é ainda mais interessante para os medievalistas, não apenas porque está cronologicamente posicionado no intervalo da chamada "Baixa Idade Média", como também porque conta com duas figuras poderosas que permitem a concentração de estudos e simplificam as interpretações: Sùnjáta Keita e Mūsā I. Ambos eram Mansá, isto é, "reis", e enquanto o primeiro foi o fundador do "império malinês", o segundo é certamente a figura "medieval" mais conhecida da África, ao qual voltaremos mais adiante. Para além destes personagens, as interpretações historiográficas do Império do Mali sofrem dos mesmos problemas descritos acima. Pensa-se este espaço em termos de império, de fronteiras e de comércio transaariano, ignorando elementos locais. Por exemplo, o Mali não era um império aos moldes costumeiros da historiografia europeia, mas era designado também por seu denominador étnico: Mànden Kúurufáaba, ou "Grande Congregação dos Mandês" (DUMESTRE, 2011, p. 553), ou simplesmente referido a partir da cidade principal do "império", Niani (atual República da Guiné). Há também um forte elemento de oralidade sincretizada com um Islã pouco ortodoxo na formação da sociedade, aspecto pouco observado ou compreendido pelos Estudos Medievais, que preferem olhar para a estruturação política do Mànden Kúurufáaba a partir do grande influxo de ouro que marca a região (cf. BERZOCK, 2019; REECE, 2005; ROMERO, 2011).

Em outras palavras, a interpretação, ou melhor, a inserção da África no campo dos Estudos Medievais usualmente incorre em uma forma de Medievalismo Acadêmico, em especial se nos referirmos à África ao Sul do Saara. Medievalismo 
Acadêmico porque, antes de interpretações alinhadas aos Estudos Africanos e às tradições específicas das variadas sociedades africanas, a “África Medieval” é alvo de imagens, de desejos romantizados ou de atalhos de compreensão. Estas imagens estão em uma encruzilhada que une pontos clássicos da medievalística, como políticas feudais, lógicas aristocráticas e dinâmicas imperiais, e questões mais urgentes do mundo contemporâneo, como o desejo de enxergar, na África, um espaço de riquezas que faça contraponto à realidade colonial e pós-colonial deixada pelo imperialismo europeu. Há, então, um esforço para colocar a África ao Sul do Saara em pé de igualdade, historiograficamente falando, com a Europa. Estas proposições, contudo, carregam problemas tanto de cunho epistemológico quanto de cunho político.

No campo epistemológico, temos um falseamento ou um completo apagamento das características das sociedades africanas "medievais". ${ }^{7} \mathrm{Em}$ primeiro lugar, a análise privilegia estados e organizações políticas que ou possam ser vistas de formas semelhantes àquelas compreendidas na Europa ou na Ásia Ocidental, como dito acima, ou que possuam algum tipo de contato com o Ocidente Medieval. Assim, os "Reinos Sudaneses" são foco de investigação, em grande parte, porque sua existência é necessária para a compreensão das rotas comerciais através do Saara. Isso os conecta tanto com o Norte da África quanto com a Europa e a Ásia Ocidental, já que o ouro das minas africanas ocidentais compõe um importante elemento de troca no espaço mediterrânico. Em certa medida, é possível dizer que este movimento opera uma subalternização das sociedades Soninquê e Mandê, porque elas são entendidas a partir do preenchimento de lacunas historiográficas. Por isso, as esferas da África Oriental ou Austral pouco figuram neste Medievo idealizado - porque não trazem à tona uma realidade que possa ser facilmente relacionada àquela do Ocidente. Quando a África Ocidental surge na historiografia do Medievo de forma abrangente, ela surge de forma a ignorar as especificidades mencionadas acima: pouco sabemos sobre a lógica social das dinastias, sobre as categorias de pertença étnica, sobre a relação das sociedades com o trabalho, com a terra ou com a guerra, sobre a economia local, sobre as tradições orais e religiosas para além do Islã africano heterodoxo, sobre os amparos de legitimidade dos “reis" (isto é, do Gàjànıàaná e do Mansá); sabemos, tão somente, de seu papel no fornecimento de ouro e na organização das rotas transaarianas.

Em certa medida, aqui os Estudos Medievais poderiam se defender a partir do amparo na documentação. As fontes para os espaços africanos, se comparadas com o corpus europeu, são escassas. Temos, de um lado, relatos 
e tradições orais compiladas e transcritos no século XX, como o Épico de Sùnjáta Keita ( $c f$. NIANE, 1995) ou o Épico de Súmanguru Kánte (cf. SAKO, 2017) e, de outro, a documentação islâmica, como os escritos de Muḥammad ibn Mūsā al-Khwārizmī, al-Bakrī, Shihāb al-Dīn al-'Umarī e Ibn Bațūța (cf. LEVTZION; HOPKINS, 2011). Lidar com estes documentos pressupõe uma série de ferramentas nem sempre disponíveis aos medievalistas do mundo europeu. Contudo, antes de recorrer, então à imagens e analogias familiares (Medievalismo Acadêmico), pesquisadores deveriam se aproximar dos Estudos Africanos e de Oralidade, como fez magistralmente Marhsall Sahlins em seu debate acerca dos antecedentes do Reino do Kongo: Sahlins recorreu à padrões africanos nos relatos orais antes de recorrer à documentação portuguesa dos séculos XVI e XVII, e a partir destes padrões, ele buscou compreender como as sociedades que formaram o Kongo dia Ntotila ("Reino do Kongo") lidavam com ancestralidade, tempo, passado, história e legitimação política (SAHLINS, 2017, p. 139-222).

No campo político, temos uma situação semelhante. Olhar para a "África Medieval" seria uma forma de circunvagar o papel tradicional atribuído ao continente nas compreensões historiográficas: o de um espaço que começa a existir quando os Europeus passam a traficar escravizados e, posteriormente, quando a África é dividida e rapinada no auge do imperialismo dos séculos XIX e XX. A condição padrão do continente africano na historiografia (mas também na consciência histórica popular) é a de subalternidade, portanto. Ele só existe enquanto anexo de uma narrativa centralizada na Europa. Este movimento também abarca, em maior ou menor medida, a Ásia e o “Novo Mundo”, mas como aponta Valentin Mudimbe, a África, por uma série de razões, sofre com imagens e racializadas (MUDIMBE, 2019, p. 17-51).É neste sentido, numa acepção política (e ideológica), que os Estudos Medievais seriam um caminho para apresentar ao mundo uma África independente dos europeus, independente dos processos de escravização, colonialismo e imperialismo - olhando para o continente antes da Modernidade, poderíamos ver a África falando por si mesma. Por certo que intentos como este são necessários e louváveis, mas resta uma questão: os Estudos Medievais podem, realmente, fazer isso? Se voltarmos ao problema epistemológico acima, veremos que não (ao menos, não ainda). Isto porque, ao cair no Medievalismo Acadêmico que gesta uma Idade Média africana que, em realidade, pouco condiz com as especificidades das plurais sociedades ao Sul do Saara, nos deparamos com a mesma situação que a Idade Média europeia enfrentou no século XIX: visões românticas e instrumentalizadas. A primeira consequência direta deste processo é a do contraponto, isto é, a 
investigação histórica se torna, primordialmente, uma ferramenta discursiva em que se ressalta a riqueza do passado - riqueza material medida em ouro. Se a "África Medieval" é uma outra África, rica e pujante, em contraponto à África submetida ao imperialismo e ao tráfico humano, qual a mensagem subentendida? A de que o presente carece destas mesmas riquezas. Afinal, a "África Medieval" é uma imagem idealizada, ela não se traduz na realidade e, então, a realidade do presente tem, justamente, a pobreza e os horrores da exploração colonial ressaltados como grande ponto de identidade. A segunda consequência é a da simplicidade, isto é, a pesquisa visa apenas reforçar um cenário previamente imaginado: a da África rica em ouro. Dessa forma, o ouro se torna o verdadeiro protagonista histórico, eclipsando, apenas para citar um exemplo, a própria concepção Soninquê ou Mandê sobre economia e sua relação real e material com o ouro. A terceira consequência é a da antítese, diretamente relacionada com o contraponto: se a "África Medieval" precisa se diferenciar da "África Contemporânea", ela precisa também evitar pontos que relacionem as duas. Aqui, o maior exemplo é o estudo acerca dos mecanismos de escravização. No caso do "Império do Mali”, ou Mànden Kúurufáaba, a manutenção das estruturas políticas dependia de intrincadas relações interfamiliares de trabalho, submissão e confronto - relações que envolviam também elementos étnicos e sócio-econômicos. Uma das formas de submissão era a escravização não-racial: é dito que, em sua peregrinação à Meca, Mansá Mūsā I levou consigo sessenta mil homens, nos quais se incluíam doze mil escravizados (KANE, 2016, p. 51). Apesar do eventual exagero nos números, não há dúvida de que o entourage de Mūsā I era considerável, e certamente existia uma complexa estrutura de poder que amparava este nível de controle. Os números também revelam uma possível verve bélica em Mūsā I, já que a maior parte dos escravizados na sociedade Mandê eram prisioneiros de guerra. Pode-se dizer, então, que no Mànden Kúurufáaba era o sucesso militar que garantia a manutenção da autoridade, e não a riqueza em ouro. Contudo, por conta do contraponto, da simplicidade e, especialmente, da antítese, Mansá Mūsā I não é visto como guerreiro e estrategista, mas essencialmente como "Rei do Ouro" (SUTTON, 1997, p. 221-222). Por conta disso, revistas populares de alta circulação constantemente afirmam que Mansá Mūsā I foi o homem mais rico que já existiu, com uma fortuna estimada em algo equivalente a meio trilhão de dólares hoje em dia. ${ }^{8}$ Esta estimativa leva em conta a posse de ouro, e não a autoridade sobre famílias, guerreiros, trabalhadores e escravizados. Contudo, as minas de ouro do Mànden Kúurufáaba faziam parte da terra, mas o poder, 
ao contrário do que vemos no Ocidente Medieval, se dava a partir do controle humano, não da posse de terras. Por isso, o verdadeiro poder de Mūsā I estava no monopólio da mão de obra exploratória, não nas terras ou nos minérios em si. Reduzir Mūsā I à "Rei do Ouro" reduz também a possibilidade de sua compreensão histórica.

Neste sentido, Mansá Mūsā I é um estudo de caso paradigmático para que compreendamos o Medievalismo - Acadêmico e Popular - que se aplica à África ao Sul do Saara. Voltemos, então, a ele.

\section{O Leão do Mali}

Em termos de Idade Média enquanto baliza cronológica, Mansá Mūsā I é, possivelmente, o personagem mais conhecido, destacado e estudado na África ao Sul do Saara. Mūsā I era neto de Abū Bakr Keita, um sobrinho do famoso Sùnjáta Keita, e reinou em um período em que o Islã já possuía uma forte base na África Ocidental, como pode ser visto pelos nomes adotados - Mūsā é a forma árabe do nome "Moisés" (NIXON; REHREN; GUERRA, 2011, p. 13531368). Por conta de sua riqueza material, como vimos acima, Mūsā I é alvo de uma vasta bibliografia acadêmica e pedagógica ( $c f$. BELL, 1972; LEVTIZION, 1963; KRASNER, 2017; ROY, 2019; SCHULTZ, 2006; ZAMOSKY, 2007). Essa atenção se explica também pela documentação: Mūsā I é mencionado por uma série de autores islâmicos, incluindo ibn Khaldūn, mas talvez o documento que mais chame a atenção seja o famoso Atlas Catalão, produzido por Abraão Cresques em 1375 ( $c f$. NOGUEIRA, 2014). O atlas de Cresques é rico em detalhes e apresenta figuras alegóricas para todas as partes do mundo conhecido algumas poucas são, de fato, personagens reais do período, e uma delas está, justamente, na África Ocidental. Um rei negro, segurando uma pepita de ouro, vem acompanhado do seguinte descritivo:

Aquest senyor negre es appellat musse melly, senyor dels negres de Gineva. Aquest rey es lo pus rich el pus noble senyor de tota esta pertida per labondançia de lor lo qual se recull en la suua terra (CRESQUES, 1375). ${ }^{9}$

Chamado ali de Musse Melly, Mūsā I figura no grande mapa como um rei poderoso e rico (figura 1), justamente a imagem que se constrói na historiografia contemporânea. 
Figura 1 - Detalhe do Atlas Catalão de Abraão Cresques (1375)

representando Mansá Mūsā I segurando uma pepita de ouro

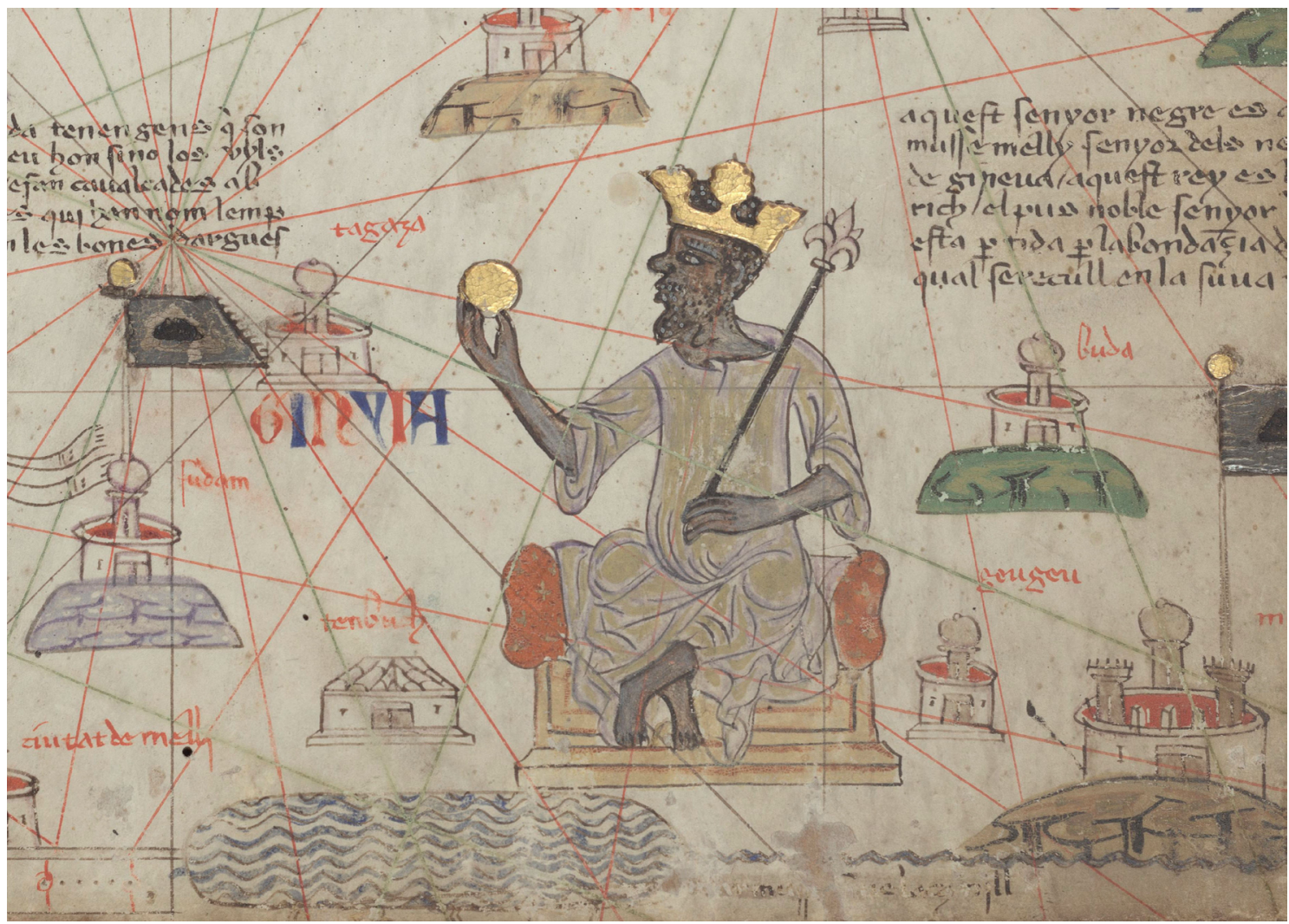

Fonte: Cresques (1375).

A representação de Mansá Mūsā I é poderosa, e influência de maneira indelével a imagem contemporânea deste governante. Em 2014, por exemplo, a National Geographic produziu um documentário, dirigido por Jason Sklaver, intitulado The Quest for Gold ("A Busca por Ouro"), que discute a relação de grandes figuras da história com a riqueza material e o ouro. Uma destas figuras é Mūsā I, que surge trajado com alentadas roupas douradas e, em um dado momento, posa para um retrato que está sendo pintado; ele segura uma pepita de ouro e a admira com autoridade, recriando o detalhe do Atlas Catalão. ${ }^{10}$ Esta percepção de riqueza que emana de Mūsā I também atinge histórias em quadrinho e a literatura infanto-juvenil: em 2001, Khephra Burns publica Mansa Musa: The Lion of Mali (cf. BURNS, 2001), contendo diversas ilustrações de autoria de Leo e Diane Dillon. Nelas, a regalidade e a riqueza de Mūsā I chamam a atenção (figura 2). 
Figura 2 - Capa do livro Mansa Musa: The Lion of Mali, de Khephra Burns. Ilustração de Leo e Diane Dillon.

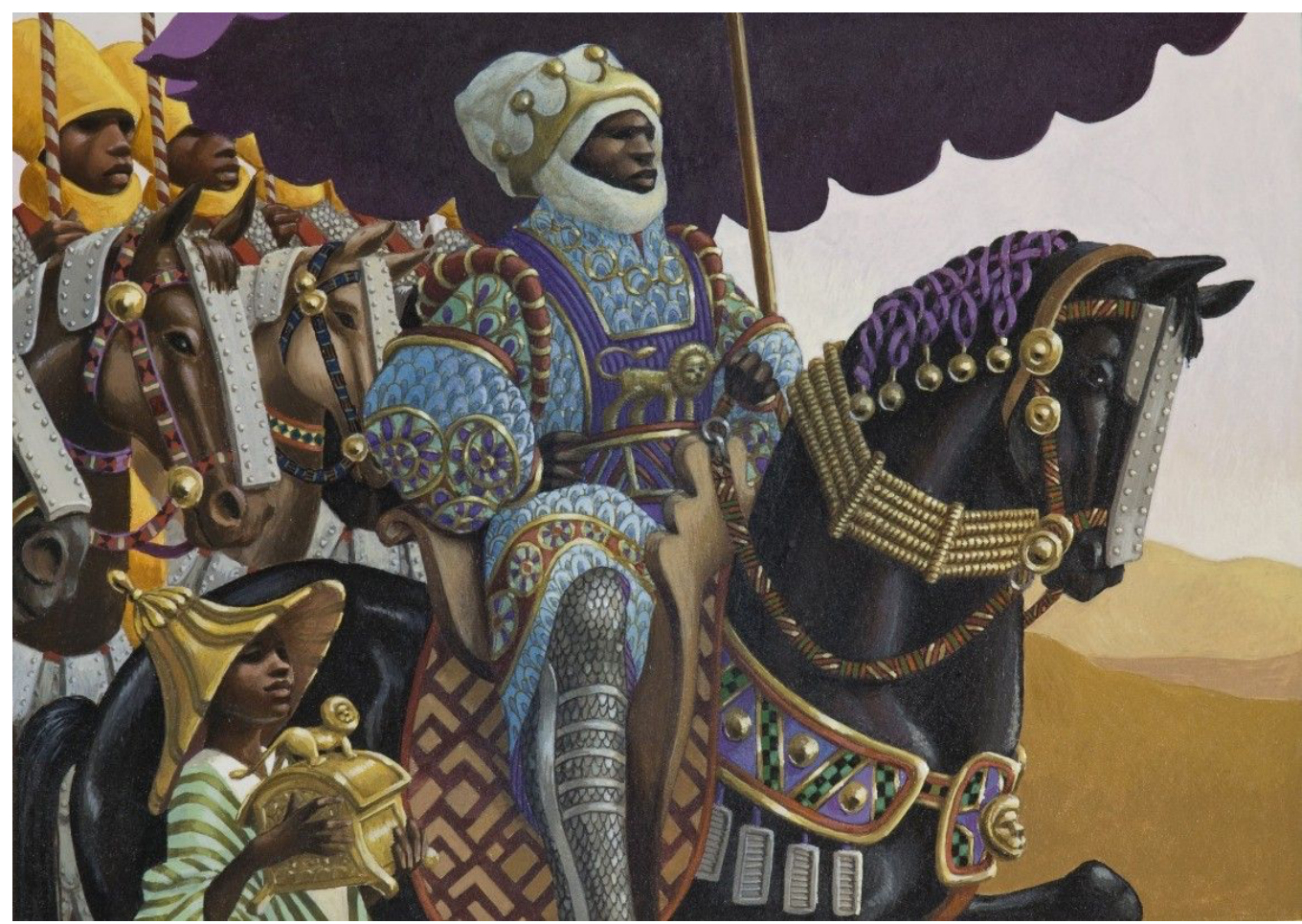

Fonte: Burns (2001).

Alguns detalhes desta ilustração de Mūsā I chamam a atenção. Ela é inspirada, certamente, na famosa peregrinação à Meca e no grande séquito que acompanha o líder. Mūsā I surge com um turbante (evocando não apenas sua fé islâmica, mas também estereótipos e imagens comuns de caravanas do deserto) e com uma coroa (inspirada no Atlas Catalão - e funcionando também como um atalho interpretativo, para sabermos que se trata de um rei). Tanto as roupas de Mūsā I quanto os aparatos dos cavalos buscam uma clara inspiração europeia, com as mangas bufantes e os brocados régios. Fica explícito, portanto, que a intenção da ilustração não era a de trazer elementos visuais verdadeiramente africanos, mas sim o de trazer elementos visuais régios, de forma que Mūsā I se torna um arquetípico nobre europeu, apenas com seu turbante e a cor de sua pele nos lembrando que a narrativa se passa, em verdade, na África.

Há, portanto, uma simbiose entre o Medievalismo Acadêmico e o Medievalismo Popular quando se trata da África. Enquanto o primeiro estabelece os parâmetros de pesquisa, ressaltando quase que exclusivamente as estruturas 
políticas da África Ocidental e seu papel na extração e na circulação de ouro, o segundo transforma a pujança áurea em imagens de inspiração, imantadas com autoridade, regalidade, poder e riqueza - ou seja, é a "Outra África”. Contudo, isto esbarra, como dito anteriormente, em percalços políticos: o foco acadêmico na riqueza mineral transfere para a África uma preocupação material que é muito mais específica da Europa, em especial após o século XV, do que dos "Reinos Sudaneses", que usavam o ouro apenas como mais um símbolo de poder. Isto incorre em imagens populares que buscam suas inspirações estéticas na Europa, e não na África, para representar líderes africanos. A estética de poder e riqueza que permeia os Medievalismos é, ao fim e ao cabo, uma estética de regalidade ocidentalizada. Este mesmo apagamento inconsciente dos aspectos africanos de poder e de visualidade se repetem em diversos outros materiais infantis, como por exemplo no Sundiata: Lion King of Mali, de David Wisniewski, e no Mansa Musa: The Richest Man In History, de Mike McCraw (cf. McCRAW, 2016; WISNIEWSKI, 1992).

\section{Conclusão: existe uma Idade Média Africana?}

Um breve levantamento da bibliografia que adota a ideia de uma África Medieval, portanto, nos revela o foco quase exclusivo na África Ocidental e nas grandes forças políticas que ali se estruturaram. Podemos argumentar que a razão por trás deste fenômeno reside na documentação disponível e nas conexões possíveis (Norte da África, Mediterrâneo, Ásia Ocidental), mas ao analisarmos a história do campo dos Estudos Medievais e as variadas manifestações do Medievalismo, podemos estabelecer uma outra interpretação: a Medievalística se volta para espaços fora da Europa que possam mimetizar as experiências históricas (e historiográficas) da própria Europa. As sociedades da África Ocidental, rodeadas de ouro e líderes poderosos, são terreno fértil para que a Academia europeia projete suas estruturas e suas categorias de análise. A Idade Média, ao invés de ser "decolonizada”, se expande, abarca mais espaços sob um mesmo manto epistemológico. Em outras palavras, ela busca colonizar narrativas históricas outras.

Por isso, enquadrar a África ao Sul do Saara no espaço da "Idade Média Global” sem um real aparato crítico é uma forma de Medievalismo - é um Medievalismo de exportação, que homogeneíza, padroniza, categoriza e monta uma percepção de realidade histórica que responde tão somente aos anseios da Academia Ocidental. A aplicação acrítica de uma "cronologia medieval", em 
outras palavras, visa não a inclusão, mas a expansão, porque mesmo que se busca descentralizar a Europa, o que se tem é uma busca por espaços históricos que travem contato com o Medievo europeu, que ainda permanece na base e no centro do campo de estudos. Isso explica porque, como dito anteriormente, as sociedades pré-Colombianas, como os Maya, os Nahuátl ou os Marajoara, nunca são incluídos no escopo do Medieval: porque estes atores históricos não estabelecem contato ou formas de integração com o "Velho Mundo". Se para ser Medieval é necessário ter alguma forma de ligação com a Afro-Eurásia, então na verdade estamos ainda assim falando de Estudos Medievais nacionalizados.

Ao discutir os problemas de uma historiografia comparativa intercultural aplicada para espaços nos europeus, Sebastian Conrad afirma que:

$$
\begin{aligned}
& \text { mais do que refletir sobre o processo de uma suposta } \\
& \text { "modernização" da disciplina histórica, uma comparação } \\
& \text { intercultural da historiografia deveria tomar as origens europeias } \\
& \text { da História Acadêmica como seu ponto departida.A razão disso[...] } \\
& \text { é que em países não-europeus a genealogia europeia da História } \\
& \text { enquanto disciplina continua a estruturar as interpretações do } \\
& \text { passado. Tanto em termos de método, mas mais importante, em } \\
& \text { termos de estratégias interpretativas, "Europa" se mantém como } \\
& \text { o polo para explicações historiográficas (CONRAD, 1999, p. 67) }
\end{aligned}
$$

Esta reflexão cabe à “África Medieval”. Buscar o Medieval (isto é, uma realidade historiográfica que foi pensada para a Europa) fora da Europa é uma forma de comparação intercultural da historiografia. E, assim, a Europa continua sendo a régua pela qual as estratégias de interpretação são produzidas. Por isso, temos em ação o Medievalismo, porque a própria historiografia interage com o passado de maneira instrumentalizada e o reinterpreta de acordo com perspectivas essencialmente contemporâneas.

Certamente, este texto não é voltado como uma crítica para o estudo da África Ocidental ou mesmo para o estudo da Europa Medieval. Mas se estamos diante da intenção de "globalizar" a perspectiva do Medievo e torna-lo consonante com preocupações de uma realidade pós-Colonial, tão somente diluir a carga epistemológica da genealogia dos Estudos Medievais não será o suficiente, e outras estratégias são necessárias. É preciso, em primeiro lugar, compreender que o Medieval, hoje, não é apenas um marcador cronológico, porque seu nascimentoacadêmico pressupôsuma nacionalização.Portanto, uma abordagem 
historiográfica que se pretenda inclusiva precisa criar uma oposição real com os elementos que a tornem exclusiva; assim, o designativo "pré-Moderno", neste sentido, é adequado, porque indica que a narrativa histórica que será colocada em foco precede justamente o que a torna excludente: a noção de Modernidade Europeia, que forja uma narrativa mestra e universal no qual a Europa detém o protagonista. A divisão cronológica formal (História Antiga - História Medieval - História Moderna) é produto exatamente desta Modernidade (DUSSEL, 2005, p. 25-34). Assim, uma historiografia mais global só poderá ser pós-Colonial se abandonar as estruturas da Modernidade exclusionária de pensamento, e isso inclui periodizações comprometidas com essas estruturas. Por isso, seria possível falar de uma Afro-Eurásia pré-Moderna sem incorrer no risco imediato de exportar interpretações e Medievalismos. Outra estratégia fundamental para a inclusão da África ao Sul do Saara em uma cronologia integrativa anterior ao século XV ou XVI talvez soe óbvia, mas precisa ser dita: as temporalidades africanas não se alteram simplesmente porque o Medievo europeu se esgota no século XV. Estruturas culturais, sociais e políticas na África ao Sul do Saara obedecem ao ritmo próprio, e não ao ritmo do Medievalismo Acadêmico. Por isso, africanistas que poderiam ser vistos como "modernistas", porque estão longe das temporalidades medievais, podem ter muito a contribuir para os Estudos préModernos. Nomes como Ousmane Kane, Vincent Monteil, Oyěwùmí, Oyèrónkẹ́ e Achille Mbembe, ainda que abordem realidades temporais muito mais próximas do contemporâneo, auxiliam na compreensão da História ao Sul da Saara porque nos lembram que os fenômenos históricos africanos não seguem o ritmo dos fenômenos históricos europeus (cf. KANE, 2016; MBEMBE, 2007; MONTEIL, 1980; OYÈWÙMÍ, 2011). Uma terceira estratégia já existe na teoria, mas precisa ser colocada em prática: interdisciplinaridade. Pensar a África préColonial é inviável sem um verdadeiro aporta da antropologia, da etnologia e da arqueologia. É fundamental que os Estudos Medievais, se quiserem adentrar o campo da Afro-Eurásia pré-Moderna, entendam que outras disciplinas, neste caso, não são apenas ferramentas, mas são integrais para a compreensão das narrativas históricas africanas, para a lida com a documentação, com as lógicas internas, etc. A pré-Modernidade, por essência, deve ser entendida a partir de um largo aporte interdisciplinar.

Em suma, este artigo buscou questionar o uso indiscriminado do termo Medieval dentro da própria Academia, apontando que sua aplicação sem a devida crítica desemboca em uma forma de Medievalismo, porque cria interações romantizadas com o passado. O Medieval não pode ser dissociado de 
sua genealogia acadêmica sem uma discussão epistemológica verdadeiramente pós-Colonial - algo que a designação cronológica "pré-Moderno", ao invés de "Medieval”, pode permitir. As plurais histórias da África ao Sul do Saara não precisam estar subordinadas aos esquemas interpretativos eurocentrados; sem essa crítica, não temos nada além de uma África Made in Medieval Europe.

\section{Referências}

ALTSCHUL, Nadia R. Postcolonialism and the study of the middle ages. History Compass, Hoboken, v. 6, n. 2, p. 588-606, 2008.

AURELL, Jonas. El nuevo medievalismo y la interpretación de los textos históricos. Hispania: Revista Española de Historia, Madri, v. 66, n. 224, p. 809-831, 2006.

BARROS, José Deomar. Teoria da história: a escola dos Annales e a nova história. Petrópolis: Vozes, 2012. v. 5.

BELL, Neil M. The age of Mansa Musa of Mali: problems in succession and chronology. The International Journal of African Historical Studies, Boston, v. 5, n. 2, p. 221-234, 1972.

BERZOCK, Kathleen Bickford. Caravans of gold, fragments in time: art, culture, and exchange across medieval saharan Africa. Princeton: Princeton University Press, 2019.

BJERK, Paul. Building a peaceful nation: Julius Nyerere and the establishment of sovereignty in Tanzania, 1960-1964. Rochester: Rochester University press, 2015. BURNS, Kimberly. Mansa Musa: the lion of Mali. Illustration L. Dillon, D. Dillon. Nova Iórque: Gulliver Books, 2001.

BURR, George Lincoln. Anent the middle ages. The American Historical Review, Washington, v. 18, n. 4, p. 710-726, 1913.

COHEN, Jeffrey Jerome. Midcolonial. In: COHEN, J. J. (org.). The postcolonial middle ages. Nova Iórque: Palgrave, 2000. p. 1-19.

CONRAD, David C. Empires of medieval west Africa: Ghana, Mali, and Songhay. Nova Iórque: Facts on File, 2005.

CONRAD, Sebastian. What time is Japan?: problems of comparative (intercultural) historiography. History \& Theory, Hoboken, v. 38, n. 1, p. 67-83, 1999. 
COSTA E SILVA, Alberto. A enxada e a lança: a África antes dos portugueses. Rio de Janeiro: Nova Fronteira, 2009.

CRESQUES, Abraham. Abraham Cresques ? Atlas de cartes marines, dit [Atlas catalan]. Paris: Bibliothèque Nationale de France - Gallica, 1375. Manuscrito. Departamento de Manuscritos - Espagnol 30, identificador ark:/12148/btv1b55002481n. Disponível em: https://gallica.bnf.fr/ark:/12148/ btv1b55002481n. Acesso em: 28 maio 2020.

D'ARCENS, Louise. (org.). The Cambridge companion to medievalism. Cambridge: Cambridge University Press, 2016.

DAVIDSON, Jacob. As 10 pessoas mais ricas de todos os tempos. Money, Dorado, 30 jul. 2015. Disponível em: https://money.com/the-10-richest-people-of-alltime-2/. Acesso em: 27 maio 2020.

DONN, L.; DONN, D. Ancient and medieval Africa. [s. l.]: Social Studies Service, 2012.

DUMESTRE, Gérard. Dictionnaire Bambara-Français, suivi d'un index abrégé Français-Bambara. Paris: Karthala, 2011.

DUSSEL, E. Europa, Modernidade e eurocentrismo. In: LANDER, E. (org.). $A$ colonialidade do saber: eurocentrismo e ciências sociais: perspectivas latinoamericanas. Buenos Aires: CLACSO, 2005. p. 25 - 34.

EMERY, Enrique. The "Truth" about the middle ages: la revue des deux mondes and late nineteenth-century French medievalism. Prose Studies, Abingdon-onThames, v. 23, p. 99-114, 2000.

FARIAS, Paolo Fernando Moraes. Arabic medieval inscriptions from the republic of Mali: epigraphy, chronicles and songhay-tuareg history. Oxford: Oxford University Press, 2003.

FAUVELLE, François-Xavier. Le rhinocéros d'or: histories du moyen âge africain. Paris: Alma Editeur, 2013.

FREEMAN-GRENVILLE, Greville Stewart Parker. The medieval history of the Tanganyika Coast. Oxford: Oxford University Press, 1962.

FUGELSO, Karl. (org.). Studies in medievalism XIX: defining neomedievalism(s). Cambridge: D. S. Brewer, 2010. 
FUHRMANN, Horst. 'Sind eben alles menschen gewesen': gelehrtenleben im 19. und 20. jahrhundert: dargestellt am beispiel der monumenta germaniae historica und ihrer mitarbeiter. Munique: C. H. Beck, 1996.

GARLAKE, Peter. Afrika und seine Königreiche. Berlim: Europäische Bildungsgemeinschaft, 1975.

GAUNT, Simon. Can the middle ages be postcolonial?. Comparative Literature, Durham, v. 61, n. 2, p. 160-176, 2009.

GEARY, Patrick J.; KLANICZAY, Gábor. (org.). Manufacturing middle ages: entangled history of medievalism in nineteenth-century europe. Leiden: Brill, 2013.

GEARY, Patrick J. O mito das nações: a invenção do nacionalismo. São Paulo: Conrad, 2002.

GOCKING, Roger. The history of Ghana. Westport: Greenwood Press, 2005.

GOMEZ, Michael. African dominion: a new history of empire in early and medieval west Africa. Princeton: Princeton University Press, 2017.

GOODWIN, A. J.H. The medieval empire of Ghana. The South African Archaeological Bulletin, Vlaeberg, v. 12, n. 47, p. 108-112, 1957.

HALL, Martin; STEFOFF, Rebecca. Great Zimbabwe. Oxford: Oxford University Press, 2006.

HALLAM, Henry. View of the state of europe during the middle ages. Nova Iórque: W. J. Widdleton, 1866.

KANE, Ousmane Oumar. Beyond timbuktu: an intellectual history of muslim west Africa. Cambridge: Harvard University Press, 2016.

KAUFMAN, Amy. Medieval unmoored. In: FUGELSO, K. (org.). Studies in medievalism XIX: defining neomedievalism(s). Cambridge: D. S. Brewer, 2010. p. $1-11$.

KIRKMAN, James. The excavations at Kilepwa: an introduction to the medieval archaeology of the Kenya Coast. The Antiquaries Journal, New York, v. 32, n. 3/4, p. 168-184, 1952.

KRASNER, Barbara. Mansa Musa: the most famous African traveler to Mecca. 
New York: Rosen Publishing, 2017.

LANGE, Dierk. Ein vernachlässigtes Forschungsgebiet: die Geschichte des westafrikanischen Mittelalters. Saeculum, Göttingen, v. 43, n. 4, p. 291-306, 1992. LEVTIZION, Nehemiah. The thirteenth- and fourteenth-century kings of Mali. The Journal of African History, Cambridge, v. 4, n. 3, p. 341-353, 1963.

LEVTZION, Nehemia; HOPKINS, John F. P. (ed.) Corpus of early Arabic sources for West African history. Princeton: Markus Wiener Publishers, 2011.

MALOBA, Wunyabari O. Mau Mau and Kenya: an analysis of a peasant revolt. Indianapolis: Indiana University Press, 1998.

MANSA Musa net Worth. Celebrity Net Worth, [S. l.], 2012. Disponível em: https:// www.celebritynetworth.com/richest-politicians/royals/mansa-musa-networth/. Acesso em: 27 maio 2020.

MASONEN, Pekka. The Negroland Revisited: discovery and invention of the sudanese middle ages. Helsinki: Finnish Academy of Science and Letters, 2000.

MATTHEWS, David. From mediaeval to mediaevalism: a new semantic historic. The Review of English Studies, Oxford, v. 62, n. 257, p. 695-715, 2011.

MATTHEWS, David. Medievalism: a critical history. Suffolk: Boydell \& Brewer, 2015.

MBEMBE, Achille. Afropolitanism. In: NJAMI, S. (ed.). Africa remix: contemporary art of a continent. Joanesburgo: Jacana, 2007. p. 26 - 30.

McCRAW, Mary. Mansa Musa: the richest man in history. [S. l.]: Mike the Wolf, 2016.

McKISSACK, Patricia; MCKISSACK, Fredrick. The royal kingdoms of Ghana, Mali, and Songhay: life in medieval Africa. New York: Macmillan, 1995.

MIGLIO, Massimo. Giovanni Andrea Bussi: prefazioni alle edizioni di Sweynheym e Pannartz. Milão: II Polifilo, 1978.

MOMMSEN, Theodore E. Petrarch's conception of the 'dark ages'. Speculum, Chicago, v. 17, n. 2, p. 226-242, 1942.

MONTEIL, Charles. La légende du Ouagadou et l'origine des Soninké. Mémoires de l'Institut français d'Afrique noire, Dakar, n. 23, p. 359-408, 1953. 
MONTEIL, Vincent. Islam noir: une religion à la conquëte de l'Afrique. Paris: Seuil, 1980.

MORGAN, Thad. This 14th-Century african emperor remains the richest person in history. History, [S. l.], 19 mar. 2018. Disponível em: https://www.history.com/ news/who-was-the-richest-man-in-history-mansa-musa. Acesso em: 27 maio 2020.

MOUSSA, Diagana Ousmane. Dictionnaire soninké-français. Paris: Karthala, 2013. MUDIMBE, Valentin Yves. A invenção da África: gnose, filosofia e a ordem do conhecimento. Petrópolis: Vozes, 2019.

NIANE, Djibril Tamsir. Sundiata: an epic of old Mali. Burnsville: Demco Media, 1995.

NIXON, Sam; REHREN, Thilo; GUERRA, Maria Filomena. New light on the early islamic west African gold trade: coin moulds from Tadmekka, Mali. Antiquity, Cambridge, v. 85, n. 330, p. 1353-1368, 2011.

NOGUEIRA, Magali Gomes. A participação judaica na cartografia medieval maiorquina. Cadernos de Língua e Literatura Hebraica, São Paulo, n. 11, 2014.

OLIVER, Roland Anthony; ATMORE, Anthony. Medieval Africa, 1250-1800. Cambridge: Cambridge University Press, 2001.

OYÈWÙMÍ, Oyèronké (ed.). Gender epistemologies in Africa: gendering traditions, spaces, social institutions and identities. Londres: Palgrave, 2011.

REECE, Katherine. West African kingdoms: empires of gold and trade. Vero Beach: Rourke, 2005.

REUTER, Timothy. Medieval: another tyrannous construct? The Medieval History Journal, Newbury Park, v. 1, n. 1, p. 25-45, 1998.

RICHARDSON, MichaelScott. Medievalism, historicism, and nationalism in early nineteenth-century German Opera. 2016. Tese (Doutorado em Teoria Musical) Stony Brook University, Stony Brook, 2016.

ROBERTS, Helene. The Medieval spirit of pre-raphaelitism. In: CHEENEY, L. (org.). Pre-raphaelitism and medievalism in the arts. Lewiston: The Edwin Mellen Press, 1992.p. 15 - 28. 
ROMERO, Flora. Reinos sudaneses - pujança econômica e cultura na África medieval. Revista Tempo, Espaço, Linguagem, Ponta Grossa, v. 2, n. 3, p. 187-197, 2011.

ROY, J.-L. Mansa Musa I, king of kings: the great pilgrimage of an African king from Africa to Arabia, 1324-1325. Oakville: Mosaic Press, 2019.

SAHLINS, Marshall. the atemporal dimensions of history: in the old Kongo Kingdom, for Example. In: GRAEBER, D.; SAHLINS, M. On kings. Londres: HAU Books, 2017. p. 139 - 222.

SAKO, Akinori. The epic of sumanguru kante. Boston: Brill, 2017.

SCHAEFFER, Peter. The emergence of the concept "medieval" in central european humanism. The Sixteenth Century Journal, Kirksville, v. 7, n. 2, p. 21-30, 1976.

SCHULTZ, Warren. Mansa Mūsā's gold in Mamluk Cairo: a reappraisal of a world civilizations anecdote. In: PFEIFFER, J.; QUINN, S. A. (org.). History and historiography in Post-Mongol Central Asia and the middle east: studies in Honor of John E. Woods. Wiesbaden: Harrassowitz Verlag, 2006. p. 428-450.

SPIEGEL, Gabrielle. Épater les médiévistes. History and Theory, Hobokne, n. 39, p. 243-250, 2000.

STOKES, L. K. Medievalism in early nineteenth-cenury German musical thought. In: MEYER, S. C.; YRI, K. (org.). The oxford handbook of music and medievalism. Oxford: Oxford University Press, 2020. p. 17-37.

SUTTON, John E. G. The Africa lords of the intercontinental gold trade before the black death: Al-Hasan bin Sulaiman of Kilwa and Mansa Musa of Mali. The Antiquaries Journal, Cambridge, n. 77, p. 221-242, 1997.

THE QUEST for gold. Directed by Jason Sklaver. [S.l.: National Geographic], 2014. 1 video ([45 min?]), color. Disponível em: https://www.nationalgeographic.com. au/videos/quest-for-gold/mansa-musas-golden-empire-3540.aspx. Acesso em: 25 maio 2020.

UTZ, Richard. Coming to terms with medievalism. European Journal of English Studies, Londres, v. 15, p. 101-113, 2011.

VENTER, Pieter Michiel. Understanding the concept of "time" in Daniel. Verbum et Ecclesia, Cidade do Cabo, v. 21, n. 3, p. 666-681, 2000. 
VERDUIN, Kathleen. The founding and the founder: medievalism and the legacy of Leslie J. Workman. Studies in Medievalism, Suffolk, v. 17, p. 1-27, 2009.

WISNIEWSKI, David. Sundiata: Lion King of Mali. Nova Iorque: Clarion, 1992.

WOOD, I. N. Literary composition and the early medieval historian in the nineteenth century. In: LOUD, G.; STAUB, M. (org.). The making of medieval history. New York: York Medieval Press, 2017. p. 37-54.

WOOD, I. N. The modern origins of the early middle ages. Oxford: Oxford University Press, 2013.

WYNNE-JONES, Stephanie; LAVIOLETTE, Adria. The swahili world. Londres: Routledge, 2018.

ZAMOSKY, Lisa. Mansa Musa: leader of Mali. Huntington Beach: Teacher Created Materials, 2007

\section{Notas}

${ }^{1}$ Professor de História da África no Departamento de História da Universidade Federal do Paraná (UFPR).

${ }^{2} \mathrm{~A}$ ideia central deste artigo nasce a partir das discussões, cada vez mais comuns nos fóruns públicos e encontros acadêmicos voltados para o estudo da Idade Média, acerca dos limites geográficos (e ideológicos) do construto cronológico Medieval. Destaca-se, em especial, as contribuições de José Rivair Macedo, professor de História da África da Universidade Federal do Rio Grande do Sul, para este debate. Deixo registrado, portanto, meus agradecimentos (e meu débito) ao professor Macedo.

${ }^{3}$ Ainda que discutir as complexidades que envolvem a separação do Medievalismo como apropriação e do Medievalismo como campo de estudo - e os vários conceitos e neologismos que surgem dessa separação - não seja, aqui, meu objetivo, cabe lembrar que esta é uma discussão bastante polêmica e, justamente por isso, aberta à constantes revisões e contestações. Para mais sobre este debate, $c f$. D’Arcens (2016); Matthews (2015); Fugelso (2010).

${ }^{4}$ Farias nota, contudo, que a terminologia do Medieval, apesar de sua aplicação em sua obra, não é apropriada para uma realidade africana (FARIAS, 2003, p. xxiii).

${ }^{5}$ Há muitos estudos sobre diversas temporalidades e diversos espaços africanos, mas por várias razões, costuma existir uma forte divisão departamental. A arqueologia e a antropologia constantemente se dedicam à importantes elementos das culturas africanas e estes resultados de pesquisa acabam dialogando pouco com a produção acadêmica em História - em especial nos Estudos Medievais. Alguns exemplos de obras fundamentais para se entender a África pré-Moderna, mas que pouco figuram nas listas bibliográficas dos medievalistas são Wynne-Jones e Laviolette (2018); Costa E Silva (2009); Hall e Stefoff (2006); Monteil (1980); Garlake (1975). 
${ }^{6}$ Apesar desta generalização grosseira, é sabido que, já no começo do século XX, pesquisadores franceses ligados à Escola dos Annales criticavam a ênfase dada pela história aos "homens ilustres" e ao protagonismo político de reis, imperadores, generais, etc. Este foco na individualidade é fruto das origens nacionalistas da historiografia e, mesmo que criticados e largamente superados, ainda "assombram" as discussões acadêmicas ( $c f$. BARROS, 2012).

"Situação semelhante ocorre com os Estudos Japoneses e a ideia de um "Japão Feudal": o período compreendido entre os séculos XII e XV tem suas especificidades culturais, sociais, políticos e econômicas apagadas e transformadas apenas em uma forma japonesa de "feudalismo", resumindo complexas estruturas históricas em uma relação de poder entre senhores de terra e seus exércitos (CONRAD, 1999, p. 67-83).

${ }^{8}$ Existem dezenas de reportagens, em diversas línguas, sobre a riqueza de Mansá Mūsā. A fonte mais citada para estas matérias é uma coluna do Celebrity Net Worth (MANSA..., 2012) Vale também destacar a reportagem de 2015, The 10 Richest People of All Time (DAVIDSON, 2015), e a coluna de 2018, This 14th-Century African Emperor Remains the Richest Person in History (MORGAN, 2018).

${ }^{9}$ Este senhor negro é chamado Musse Melly (Mansá Mūsā), senhor dos negros da Guiné. Este rei é o mais rico e o mais nobre senhor de toda a região por conta da abundância de ouro que se recolhe em sua terra.

${ }^{10}$ Uma prévia do documentário - especificamente a passagem acerca de Mansá Mūsā I pode ser encontrada em: (THE QUEST..., 2014).

${ }^{11}$ Tradução, do inglês, de minha autoria. 